\title{
Saline dust storms and their ecological impacts in arid regions
}

\author{
Jilili Abuduwaili ${ }^{1^{*}}$, DongWei LIU ${ }^{1,2}$, GuangYang WU ${ }^{1,2}$ \\ ${ }^{1}$ Xinjiang Institute of Ecology and Geography, Chinese Academy of Sciences, Urumqi 830011, China; \\ ${ }^{2}$ Graduate University of Chinese Academy of Sciences, Beijing 100049, China
}

\begin{abstract}
In many arid and semiarid regions, saline playas represent a significant source of unconsolidated sediments available for aeolian transport, and severe saline dust storms occur frequently due to human disturbance. In this study, saline dust storms are reviewed systematically from the aspects of concept, general characteristics, conditions of occurrence, distribution and ecological impact. Our researches showed that saline dust storms are a kind of chemical dust storm originating in dry lake beds in arid and semiarid regions; large areas of unconsolidated saline playa sediments and frequent strong winds are the basic factors to saline dust storm occurrence; there are differentiation characteristics in deposition flux and chemical composition with wind-blown distance during saline dust storm diffusion; and saline dust storm diffusion to some extent increases glacier melt and results in soil salinization in arid regions. An understanding of saline dust storms is important to guide disaster prevention and ecological rehabilitation.
\end{abstract}

Keywords: saline dust storm; dried-up lakebed; playa; wind erosion; ecological impact

\section{Introduction}

The sources, generation, transport and sediment of dust storms have been paid significant attention by the scientific community (Reheis, 2006). Atmospheric dust affects global climate change by changing incident solar radiation (Tegen et al., 2004), affects the economy and quality of life by reducing visibility, and provides basic nutrients for terrestrial and aquatic ecosystems (Okin et al., 2004). The development of Remote Sensing and Geographic Information System technologies has enabled the study of dust storms to be extended from the regional to the global scale, facilitating the characterization of dust storm atmospheric dynamics, ground conditions, spatial distribution and paths (Prospero et al., 2002; Ginoux et al., 2004; Shao and Dong, 2006). A strong theoretical foundation has been provided by the development of wind erosion models for further understanding of dust storm history and predicting the effects of climate change and land use on dust storm occurrence (Shao, 2001; Pelletier, 2006). However, the occurrence and diffusion of saline dust storms originating from dried lake beds, and their ecological effects, have not been paid enough attention. Saline dust storms are a special kind of dust storm formed by wind erosion of salt-rich sediments in saline playas (Micklin, 2007; Abuduwailli et al., 2008). Compared with common dust storms, saline dust storms transport high concentrations of fine-grain saline and alkaline material, such as sodium sulfate, sodium chloride, and other potentially toxicity components which stimulate glacier melt and soil salinization, poison ground vegetation, and seriously threaten the ecological security of arid regions (Small et al., 2001; Mu et al., 2002; Singer et al., 2003a; Erdinger et al., 2004; Abuduwaili and Mu, 2006). Therefore, understanding saline dust storms and their mechanisms of landscape change is essential for facilitating ecological environmental rehabilitation in arid regions. In this paper, we review systematically the general characteristics of saline dust storms from the aspects of concept, conditions of occurrence, distribution, transport, ecological impacts, and prevention.

\section{Concept and characteristics}

Currently, there is as yet no unitary concept of saline

Received 2010-03-10, accepted 2010-04-12

doi: $10.3724 /$ SP.J.1227.2010.00144

"Corresponding author: Jilili Abuduwaili (E-mail: jili1@ms.xjb.ac.cn) 
dust storms in term of science. Based on our research over many years, saline dust storms are defined as a kind of weather disastrous phenomenon in arid and semiarid regions caused by dust deflated from the salt-rich sediments of dried lake beds and strongly salinized soils on the margins of lake floors.

The sources of saline dust storms differ from those of silty dust storm. The sources of common dust storms are mainly deserts, such as the Sahara in North Africa, the Taklimakan Desert in Tarim Basin, the Badain Juran Desert and its peripheral sandy lands in the Hexi Corridor in China, the Karakum Desert in Central Asia, the Gobi desert in the China-Mongolia frontier region and northern part of the Indian subcontinent with high occurrence of dust storms (Ginoux et al., 2004; Shao and Dong, 2006). In contrast, the sources of saline dust storms are mainly dried lake beds or similar landforms. These are secondary salt desert landscapes formed by hydrological imbalance, shrinkage of lake area, evaporation of high-salinity groundwater, and salt accumulation on the dried-up lake floors in drainage basins due to human activities (Gill, 1996; Blank et al., 1999). These surface sediments have a loose texture due to salt accumulation, and vegetation is sparse or absent, so wind erosion occurs easily. For example, the quantity of saline dust deflated from the Ebinur Lake in the west Junggar Basin in China was as high as $4.8 \times 10^{6} \mathrm{t}$ in the late 1990s, and the ecology of leeward oases was seriously impacted (Mu et al., 2002).

Saline dust storms also differ from common dust storms in chemical composition and grain size distribution. Saline dust storms transport high concentrations of very fine-grain dust particles with adsorbed sulphate, chloride and insecticides and some deleterious heavy metals such as $\mathrm{Mn}, \mathrm{As}, \mathrm{Rb}, \mathrm{Pb}, \mathrm{Sr}$ and $\mathrm{Cr}$ (Erdinger et al., 2004; Abuduwailli et al., 2008). Saline dust storms are therefore sometimes also referred to as white dust storms or chemical dust storms. They are difficult to prevent and control and cause serious pollution of air, soil, water and food, as well as corroding equipment, causing disease, and resulting in the degeneration of ecosystems and natural environments. The soluble salts content in dust storms over the Ebinur Lake region in China is as high as $10 \%-25 \%$ (Erdinger et al., 2004; Abuduwailli et al., 2008). The proportions of dust grains with diameters $<5 \mu \mathrm{m}$ and
$<10 \mu \mathrm{m}$ are $65.12 \%$ and $79.07 \%$, respectively (Mu et al., 2002). The average diameters of common dust storm particles in Lanzhou and Harbin cities are 11.52 $\mu \mathrm{m}$ and $28.36 \mu \mathrm{m}$, respectively (Xie et al., 2007), and are much larger than those of saline dust storm particles. Topsoil salt content in dry lake floors, the dust storm sources, reaches $57 \%$ and the proportions of sediment grain size $<4 \mu \mathrm{m}$ and $<10 \mu \mathrm{m}$ are $70 \%$ and $84 \%$, respectively ( $\mathrm{Mu}$ et al., 2002). Surface sediments in the southern and northern margins of the Taklimakan Desert, the main global sources of common dust storms, is dominated by fine sand with diameters of $125-250 \mu \mathrm{m}$ and very fine sand with diameters of $62.5-125 \mu \mathrm{m}$; their proportions are $48.35 \%$ and 35.05\%, respectively (Qian et al., 1995; Zhang et al., 2008). According to the dynamic characteristics of dust, grains with diameters $<10 \mu \mathrm{m}$ can be transported by wind for several thousands of kilometers under common wind power conditions, and those with diameters of 10-20 $\mu \mathrm{m}$ can be transported for hundreds or up to several thousands of kilometers within cyclonic storms with wind speeds $>15 \mathrm{~m} / \mathrm{s}$ (Tsoar and Pye, 1987). Therefore, once saline dust is deflated, it can be transported long distances and suspended for a long time.

Dust circulation processes differ between common and saline storms. In the former, transport is usually unidirectional, where dust is blown from the source areas to other places, and the quantity of re-deposition on source areas is very low in the short term. However, transport of saline dust is often bidirectional, and the occurrence of these storms can explain the relative stability of chemical equilibrium of the substances in the closed basins. Terminal lakes in arid regions are generally the lowest-elevation receptors of regional inflows, and receive chemical substances and sediments transported by surface runoff, subsurface flow and atmospheric deposition. On the other hand, some terminal-lake floors serve as saline dust storm sources through continual dust deflation and removal. Therefore, saline dust storms play an important role in the processes of regional geochemical circulation.

Finally, the degree of landscape damage by saline dust storms was more severe than that caused by common dust due to the substances transported and their finer grain size. Aerosolized salt grains accelerate the melt of snow cover and glaciers, and change the water 
water cycle processes of rivers in arid regions. For example, the annual quantity of saline dust deflated from the dry floor of the Aral Sea reaches $1.0 \times 10^{6} \mathrm{t}$, which accelerates the melt of snow cover and glaciers in the Tianshan Mountains and threatens the future reserves of regional fresh water resources.

\section{Conditions of occurrence and distri- bution}

Abundant unconsolidated salt-rich sediments and strong winds are the two basic conditions for saline dust storms. Therefore the areas where these dust storms occur frequently are located mostly in the terminal lake areas in arid and semiarid regions, such as the Aral Sea in Central Asia, Ebinur Lake in the west Junggar Basin, Lop Nur Lake in the east Tarim Basin and Aydingkol Lake in the Turpan Basin in China, and Owens Lake in North America (Gill, 1996; Prospero et al., 2002; Leroy et al., 2004). The areas of these dried-up lake floors are vast, containing abundant lacustrine unconsolidated saline sediments and where strong winds occur frequently, presenting the conditions for which they have become world-renowned saline dust fields (Table 1, Fig. 1).

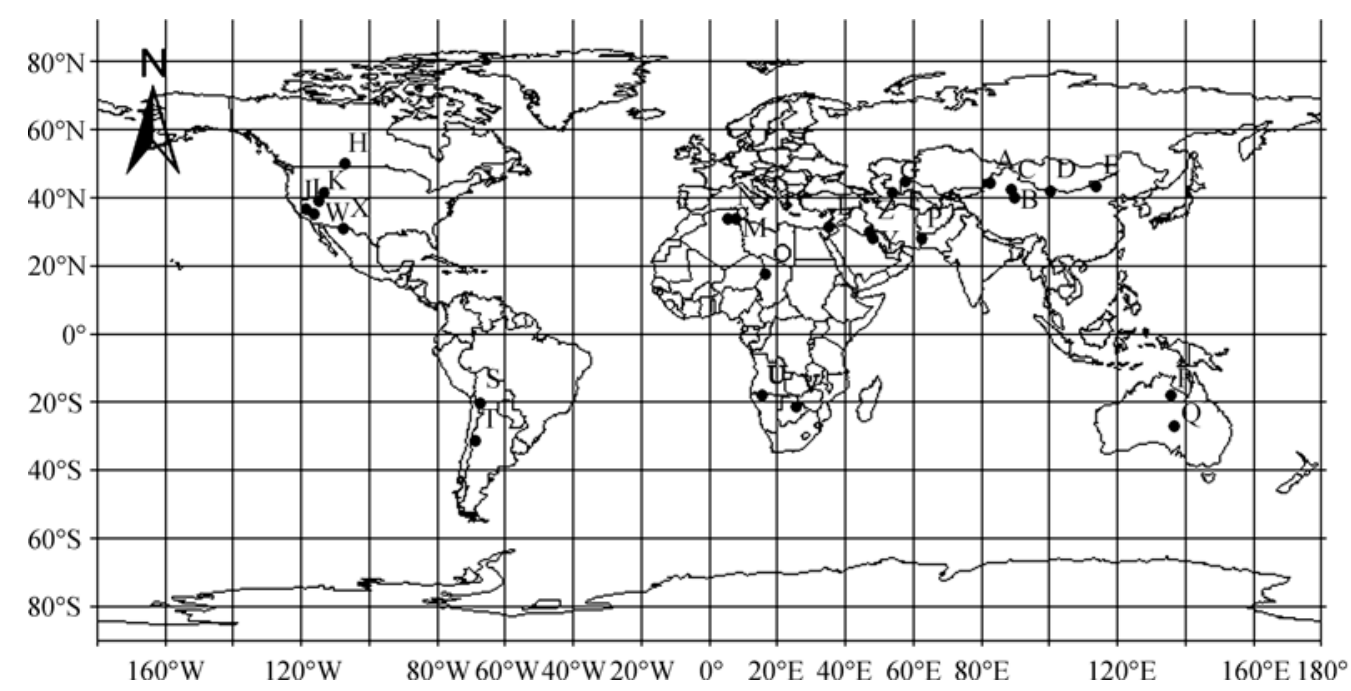

Fig. 1 Main areas of salt-rich sediments around the world (seeing Table 1 for names and locations)

Table 1 Main areas of salt dust around the world

\begin{tabular}{|c|c|c|c|}
\hline Nation & Typical dust source area (Playas or sabkha) & Nation & Typical dust source area (Playas or sabkha) \\
\hline China & Ebinur Lake (A) & Chad/Nigeria & Chad Lake (O) \\
\hline China & Lop Nur (B) & Namibia & Etosha Pan (U) \\
\hline China & Aiding Lake (C) & Botswana & Makgadikgadi Depression (V) \\
\hline China & Juyuan Sea (D) & Canada & Old Wives Lake (H) \\
\hline China & Chagannuoer Lake (E) & USA & Owens Lake (I) \\
\hline Uzbekistan & Aral Sea $(F)$ & USA & Mojave Desert (J) \\
\hline Kazakhstan & Kara Bogaz Gol (G) & USA & Great Basin playas $(\mathrm{K})$ \\
\hline Israel/Jordan & Dead Sea (L) & USA & Great Salt Lake (W) \\
\hline Iraq & Seasonal salty wastelands $(Z)$ & Mexico & Laguna Guzman (X) \\
\hline Saudi Arabia & Persian Gulf sabkha (Y) & Bolivia & Salar de Uyani (S) \\
\hline Iran & Hamun-i-Mashkel (P) & Argentina & Salinas Grandes $(\mathrm{T})$ \\
\hline Tunisia & Chott Jerid (M) & Australia & Lake Eyre (Q) \\
\hline Algeria & Chott Melrhir (N) & Australia & Barkly Tableland (R) \\
\hline
\end{tabular}

Sources: Gill (1996), Japaer and Tursunov (1996), Prospero et al. (2002), Singer et al. (2003), Leroy et al. (2006), and Reynolds et al. (2007). 
Formation of the large dry lake areas is closely related to land cover change caused by human activities in the drainage basins. Before 1960, the Aral Sea was the fourth largest inland water body in the world; it was the terminal lake of the Central Asian Amu Darya and Syr Darya Rivers, with a water area $>6.61 \times 10^{4}$ $\mathrm{km}^{2}$. The lake area was reduced sharply due to large-scale agriculture exploitation in the drainage basin from the 1960s to the 1970s. By the late 1980s the lake had diminished into two smaller water bodies (the Small Aral Sea in the north and the Large Aral Sea in the south), and the total water storage was less than $40 \%$ of that in 1960 . In January 2006, water levels of the Small Aral Sea and the Large Aral Sea were decreased by $13 \mathrm{~m}$ and $23 \mathrm{~m}$, respectively, the water area and water storage of the entire Aral Sea reduced by $74 \%$ and $90 \%$, respectively, and the area of the modern dried-up lake floor was larger than $3.0 \times 10^{4}$ $\mathrm{km}^{2}$ (Micklin, 1988, 2007).

The Ebinur Lake area was $1.31 \times 10^{3} \mathrm{~km}^{2}$ at the beginning of the 20th century. It was the terminal lake of the Bortala, Jinghe and Kuytun Rivers. However, since the 1950s the lake inflow has reduced sharply with the development of irrigated agriculture and damming of surface runoff. The lake area reduced to $500-1,200 \mathrm{~km}^{2}$, and the area of the modern dried-up lake floor is $>500 \mathrm{~km}^{2}$. Another example is Owens Lake in the United States, which was the terminal lake of Owens River. The lake dried up due to the diversion of river water into Los Angeles Penstock in 1926, and the area of dried-up salt-rich alkaline sediment reached $280 \mathrm{~km}^{2}$ (Cahill et al., 1994). After the lake shrank, shallow groundwater beneath the dry lake floor, which contained soluble salts, was transported to the ground surface due to evaporation forming salt desert. Strong winds erode the ground surface, making a sediment source for saline dust storms (Reynolds et al., 2007). Sediment yields from dry lake systems can be enormous. For example, the annual quantity of saline dust deflated from the Aral Sea is about $1.0 \times 10^{6} \mathrm{t}$; the annual dust deflated was about $4.6 \times 10^{6} \mathrm{t}$ in the Ebinur Lake (Abuduwaili and $\mathrm{Mu}, 2006$ ). Wind gusts of above $40 \mathrm{~m} / \mathrm{s}$ at Owens Lake blasted tons of sediment across the playa, generating $\mathrm{PM}_{10}$ levels as high as $40,620 \mu \mathrm{g} / \mathrm{m}^{3}$ during a $2 \mathrm{~h}$ sampling period (Cahill et al., 1994).

\section{Transport and season of occurrence}

Transport of saline dust storms is affected by many factors, such as terrain, wind power, vegetation and land use types. Because of the spatiotemporal heterogeneity of these factors and diffusion models integrating wind power and underlying land surface factors are not yet developed. Scattered-site dust-fall sample collection in the leeward zone of dust source fields, and statistical modeling, are usually applied to study saline dust transport processes (Blank et al., 1999; Abuduwaili and $\mathrm{Mu}, 2006)$. Blank et al. (1999) investigated the transport of dust and soluble salts along a transect from a barren salt-encrusted playa surface to a former pluvial lake beach and a dune-mantled upland adjacent to Eagle Valley playa from July 1994 to June 1996. They found that the content of salts in aeolian dust showed a significant correlation with dust trap location (playa, beach, and dune) and time of collection. Dust on the playa surface generally contained significantly more salts and had greater total salt flux than either the beach or the dune locations. Abuduwailli et al. (2008) conducted a study in the Ebinur Lake, and indicated the following characteristics of saline dust transport: (1) Total dust-fall and salt flux decreases with increasing transport distance from the dry lake floor source area, and the dust grain size at the monitoring site closest to the dust source is larger than that of the sediment on the dry lake floor, with finer grains not detected, having possibly been transported further downwind (Mu et al., 2002); (2) The dynamics of saline dust changes with wind intensity and season. Saline dust storms occur most frequently in spring and then autumn, due to the high frequency of strong winds in combination with a bare unconsolidated ground surface, leading to high deflated sediment flux. In winter, the lake floor is generally covered by snow or thin ice, the ground surface is frozen, and dust storms are therefore infrequent. In early spring, the snow cover melts and the ground surface thaws, evaporation increases significantly, and solutes accumulate over the lake floor to form an unconsolidated layer of frost-like evaporites. The unconsolidated evaporites are removed easily by strong winds in spring; hence the high frequency of saline dust storms in that season. In summer, the surface evaporites harden under intense sunshine and 
high evaporation to form a rough and compact salt crust. Due to lower wind speed the frequency and intensity of dust storms are reduced sharply compared with spring. The frequency of strong winds gradually increases in autumn, the salt crust is broken up by saltating sediment grains, and saline dust is mobilized, thus the second season with high frequency of saline dust storms begins (Cahill et al., 1994).

\section{Ecological effects}

Chemical substances in terminal drainage basins are redistributed by saline dust storms, and this redistribution leads to dual effects depending on the nature of transported material. On the one hand, transported ions such as $\mathrm{K}^{+}, \mathrm{Ca}^{2+}, \mathrm{Mg}^{2+}, \mathrm{NO}_{3}{ }^{-}$and $\mathrm{NH}_{3}{ }^{-}$are essential nutrients for terrestrial and aquatic ecosystems. On the other hand, transported salts, pesticides and heavy metals seriously pollute air and water, result in the degeneration of ground vegetation, and threaten the ecological security of oases. Sites close to the source areas experience especially the negative impacts of saline dust storms. Therefore, the negative impacts of saline dust storm are discussed here from three aspects: hydrological processes, soil and plants.

\subsection{Saline dust storms and glacier and snow melt}

Most rivers in arid regions depend on snow and ice melt-water supply, which have a direct impact on river hydrology and also affect watershed ecology and environment. In recent years, glacier and snow melt in the headwaters of terminal lakes have shown an accelerated tendency (Barnett et al., 2005). Researchers have attributed this to global warming but have neglected the impacts of saline dust storms on glacier and snow melt. It is known that salts are de-icing agents, commonly used to remove snow on roads. Saline dust storms are rich in $\mathrm{NaCl}, \mathrm{CaCl}_{2}, \mathrm{MgCl}_{2}$ and other chloride particles, which can be suspended in the atmosphere for long periods of time and settling on the ice and snow will increase melting. Existing research has shown that several million-tons of salt-rich dust deflates from the dry lake bed of the Aral Sea each year, accelerating the melt of glaciers and snow cover in the Pamirs and Western Tianshan Mountains (Japaer and Tursunov, 1996). Glaciers are the source of oasis stability and development in arid regions, and along with rivers constitute an inseparable, complex ecosys- tem. Moreover, mountain snow and glaciers in arid regions are important components of the world's climate system, and have significant feedback relationships influencing climate change. Thus, investigating the relationship between saline dust storms and snow/ice melt is a new and important scientific issue.

\subsection{Saline dust storms and soil salinization}

Soil salinization is the accumulation of soluble salts of $\mathrm{Na}^{+}, \mathrm{Mg}^{2+}$ and $\mathrm{Ca}^{2+}$ ions in soil, which severely reduce soil fertility. In previous research, it was considered that soil salinization in arid regions was caused by dissolved salts transported by water, i.e. soil salts were derived from solutes precipitated by groundwater evaporation (Ceuppens et al., 1997; Kotb et al., 2000). However, the role of salinization in terminal lake basins cannot be neglected, and the occurrence of saline dust storms adds another dimension to understanding the processes of salinization in arid regions. Storm-borne salt is another significant source of soil salinization. For example, the annual saline dust deposition rate in the 82nd corps, Jinghe (settlements near the Ebinur Lake) ranges $68-590 \mathrm{~g} / \mathrm{m}^{2}$, and the annual quantity of salt infiltrating into soil ranges $14-77 \mathrm{~g} / \mathrm{m}^{2}$ (Abuduwailli et al., 2008). Annually, salt-rich soil/sediments of $60-100 \mathrm{t} /\left(\mathrm{hm}^{2} \cdot \mathrm{a}\right)$ are transported from the dry floor of the Aral Sea, the saline dust deposition rate over the Amu Darya delta ranges $280-540 \mathrm{~kg} / \mathrm{hm}^{2}$ of which the deposition rate of water-soluble salts is $150 \mathrm{~kg} / \mathrm{hm}^{2}$, and local soil salinization is accelerated (Singer et al., 2003b). On different temporal and spatial scales, is it salt transported by water or blown by wind that is the dominant factor resulting in soil salinization in terminal lake basins in arid regions? What is the extent of their respective contributions to soil salinization? These are important issues needing to be investigated in the future to reveal the mechanisms of soil salinization in terminal lake basins of arid region.

\subsection{Saline dust storms and vegetation growth}

Saline dust storms contribute not only to soil salinization, but also seriously affect vegetation. When atmospheric dust settles on plant leaves, it forms a fine surface layer that absorbs plant water and blocks stomatal openings, affecting respiration and photosynthesis (Darley, 1966; Hirano et al., 1995). Saline 
dust containing $\mathrm{Mn}, \mathrm{As}, \mathrm{Rb}, \mathrm{Pb}, \mathrm{Sr}, \mathrm{Cr}$ and other harmful heavy metals can damage cells and enzymes upon entry into the plant body, thereby affecting the physiological functions (Zenk, 1996). Turhong et al. (2009) investigated the impact of salt dust on plant physiological traits. They found that certain amounts of salt dust greatly enhanced the capacity of plants to absorb $\mathrm{Na}^{+}$, while the capacity for $\mathrm{K}^{+}$absorption was greatly reduced. However, there have been no studies conducted on dose-effect relationships concerning salt dust.

\section{Prevention of dust storms}

Currently, the prevention and control measures that are implemented are mainly the diversion or conservation of water to re-cover dried lake beds to reduce wind erosion (Bao et al., 2006). However the conflict between supply and demand of water resources is becoming increasingly serious and water-saving potential is limited due to continuing social and economic development in arid regions. Moreover, evaporative losses from lake surfaces are high because of intense sunshine, large water areas, shallow water depths, and vigorous evaporation from the water surface. Therefore, the diversion or conservation of water is unsustainable.

In recent years in North America, some scholars have begun to introduce the concept of ecological restoration to prevent saline dust storms. This approach seeks to improve playa soil properties and soil-plant characteristics to improve nutrient supply and seedling survival rate of native species, thereby increasing the vegetation coverage of the exposed lake bottom to prevent wind erosion of salt-rich sediments and dust storm occurrence (Breen, 2005; Breen and Richards, 2008). The use of soil remediation to increase vegetation coverage to prevent and control saline-dust storms is a promising avenue of research and practical appli-

\section{References}

Abuduwaili J, Mu G J. Eolian factor in the process of modern salt accumulation in western Dzungaria, China. Eurasian Soil Science, 2006, 39: 367-376.

Abuduwailli J, Gabchenko, M V, Xu J R. Eolian transport of salts - a case study in the area of Lake Ebinur (Xinjiang, Northwest China). Journal of Arid Environments, 2008, 72: 1843-1852. cation.

\section{Conclusions and suggestions}

Saline dust storms are tremendously disastrous natural weather phenomenon in arid regions and occur mostly in evaporitic playa environments in arid and semiarid regions around the world. Abundant unconsolidated salt-rich sediments and strong winds are the two basic conditions of saline dust storm occurrence. There is a clear differentiation in chemical composition and deposition rate increasing transport distance between saline and common dust storms, and the dynamics of saline dust deflation and deposition are affected by wind intensity and seasonal change. Saline dust storms differ from common dust storms in aspects of dust sources, chemical composition, grain size, and circulation processes.

Saline dust storms affect glacier and snow melt and threaten climatic security and ecosystems. Moreover, dual soil salinization processes occur in arid regions resulting from solute precipitation from groundwater and accumulation of storm-borne salt. These processes cannot be neglected in researching soil salinization in terminal lake basins.

Diversion and conservation of water to increase lake inflow and keep otherwise dry lake beds submerged to reduce wind erosion is unsustainable. The research emphases in the future should be improving soil properties and survival condition of local plant species, and rehabilitating the natural lake systems to prevent and control saline dust storms in arid and semi-arid regions.

\section{Acknowledgements}

This research were funded by the Xinjiang Natural Science Foundation of China (200821162), the National Basic Research Program of China (973 Program) (2009CB825101), and the National Natural Science Foundation of China (40671170).

Bao A M, Mu G J, Zhang Y, et al. Estimation of the rational water area for controlling wind erosion in the dried-up basin of the Ebinur Lake and its effect detection. Chinese Science Bulletin 2006, 51(Suppl.1): $68-74$.

Barnett T, Adam J, Lettenmaier D. Potential impacts of a warming climate on water availability in snow-dominated regions. Nature, 
2005, 438: 303-309.

Blank R R, Young J A, Allen F L. Aeolian dust in a saline playa environment, Nevada, USA. Journal of Arid Environments, 1999, 41: $365-381$.

Breen A. Improving seedling establishment on the saline playa at Owens Lake, California through soil amendment, improved seed quality, and increased seed entrapment. University of California, 2005.

Breen A N, Richards J H. Seedling growth and nutrient content of two desert shrubs growing in amended soil. Arid Land Research and Management, 2008, 22: 46-61.

Cahill T A, Gill T E, Reid J S, et al. Saltating particles, playa crusts and dust aerosols at Owens (dry) Lake, California. Earth Surface Processes and Landforms, 1996, 21: 621-639.

Ceuppens J, Wopereis M, Miezan K. Soil salinization processes in rice irrigation schemes in the Senegal River Delta. Soil Science Society of America Journal, 1997, 61: 11-22.

Darley E. Studies on the effect of cement-kiln dust on vegetation. Journal of Air Pollution Control Association, 1966, 16: 145-150.

Erdinger L, Eck1 P, Ingel F, et al. The Aral Sea disaster-human biomonitoring of $\mathrm{Hg}$, As, $\mathrm{HCB}$, DDE, and PCBs in children living in Aralsk and Akchi, Kazakhstan. International Journal of Hygiene and Environmental Health, 2004, 207: 541-547.

Gill T E. Eolian sediments generated by anthropogenic disturbance of playas: human impacts on the geomorphic system and geomorphic impacts on the human system. Geomorphology, 1996, 17: 207-228.

Ginoux P, Prospero J M, Torres O, et al. Long-term simulation of global dust distribution with the GOCART model: correlation with North Atlantic Oscillation. Environmental Modelling and Software, 2004, 19: 113-128.

Hirano T, Kiyota M, Aiga I. Physical effects of dust on leaf physiology of cucumber and kidney bean plants. Environmental Pollution, 1995, 89: 255-261.

Japaer M, Tursunov A A. An Introduction to the Hydro-ecology in the Central Asia. Urumqi: Health Science and Technology Publishing of Xinjiang, 1996.

Kotb T, Watanabe T, Ogino Y, et al. Soil salinization in the Nile Delta and related policy issues in Egypt. Agricultural Water Management, 2000, 43: 239-261.

Leroy S A G, Marret F, Giralt S, et al. Natural and Anthropogenic Rapid Changes in the Kara-Bogaz Gol Over the Last Two Centuries Reconstructed from Palynological Analyses and a Comparison to Instrumental Records. 32nd International Geological Congress, Florence, 2004. 52-70.

Micklin P. The Aral Sea disaster. Annual Review of Earth and Planetary Sciences, 2007, 35: 47-72.

Micklin P P. Dessication of the Aral Sea-a water management disaster in the Soviet Union. Science, 1988, 241: 1170-1175.

Mu G J, Yan S, Abuduwanli J, et al. Wind erosion at the dry-up bottom of Aiby Lake - a case study on the source of air dust. Science in
China Series D-Earth Sciences (Suppl.1), 2002, 45: 157-164.

Okin G S, Mahowald N, Chadwick O A, et al. Impact of desert dust on the biogeochemistry of phosphorus in terrestrial ecosystems. Global Biogeochemical Cycles, 2004, 18: 1-9.

Pelletier J D. Sensitivity of playa windblown-dust emissions to climatic and anthropogenic change. Journal of Arid Environments, 2006, 66: $62-75$.

Prospero J M, Ginoux P, Torres O, et al. Environmental characterization of global sources of atmospheric soil dust identified with the Nimbus 7 Total Ozone Mapping Spectrometer (TOMS) absorbing aerosol product. Reviews of Geophysics, 2002, 40(1): 1002

Qian Y B, Zhang X M, Li X M. A study on grain-size features of sand material of the oases in the southern margin of the Taklimakan Desert. Journal of Desert Research, 1995, 15: 131-135.

Reheis M C. A 16-year record of eolian dust in Southern Nevada and California, USA: controls on dust generation and accumulation. Journal of Arid Environments, 2006, 67: 487-520.

Reynolds R L, Yount J C, Reheis M, et al. Dust emission from wet and dry playas in the Mojave desert, USA. Earth Surface Processes and Landforms, 2007, 32: 1811-1827.

Shao Y. A model for mineral dust emission. Journal of Geophysical Research-Atmospheres, 2001, 106: 20239-20254.

Shao Y, Dong C H. A review on East Asian dust storm climate, modelling and monitoring. Global and Planetary Change, 2006, 52: 1-22.

Singer A, Ganor E, Dultz S W, et al. Dust deposition over the Dead Sea. Journal of Arid Environments, 2003a, 53: 41-59.

Singer A, Zobeck T, Poberezsky L, et al. The PM10 and PM2.5 dust generation potential of soils/sediments in the Southern Aral Sea Basin, Uzbekistan. Journal of Arid Environments, 2003b, 54: 705-728.

Small I, van der Meer J, Upshur R E G. Acting on an environmental health disaster: the case of the Aral Sea. Environmental Health Perspectives, 2001, 109: 547-549.

Tegen I, Werner M, Harrison S P, et al. Relative importance of climate and land use in determining present and future global soil dust emission. Geophysical Research Letters, 2004, 31: 95-105.

Tsoar H, Pye K. Dust transport and questions of a desert loess formation. Sedimentology, 1987, 34: 139-283.

Turhong T, Abuduwaili J, Yilahong A, et al. Salt-dust effects on plant physiological traits at Ebinur Lake. Arid Zone Research, 2009, 26: 533-542.

Xie Y, He K, Zeng J. Feature of sand-dust sediments from a sandstorm in Harbin city. Geography and Geo-Information Science, 2007, 23: 87-91.

Zenk M. Heavy metal detoxification in higher plants - a review. Gene, 1996, 179: 21-30.

Zhang R, He Q, Kong D. Study on grain size characteristics of surface sediment in sandstorm source regions in the northern marginal zone of the Taklimakan Desert. Arid Zone Research, 2008, 25: 887-893. 